\title{
THE DISRUPTIVE REGULARISATION MECHANISM IN THE SPANISH LAW THAT CHALLENGES THE REFORM OF THE COMMON EUROPEAN ASYLUM SYSTEM ${ }^{*}$
}

\section{EL MECANISMO DE REGULARIZACIÓN DISRUPTIVO DE LA LEY MIGRATORIA ESPAÑOLA QUE DESAFÍA LA REFORMA DEL SISTEMA EUROPEO COMÚN DE ASILO}

LAURA GarcíA-Juan*

\begin{abstract}
The debate regarding the extent of EU Member States competences in immigrant integration policies was paused with the Treaty of Lisbon. European institutions took an active role in integration but did not mandate a communal approach. Consequently, each Member State instigated its own policies, which led to a wide diversity of regulations. The policy adopted by Spain stands out because of its particular approach to integration policies, which in this case are applicable to regular and irregular immigrants. A remarkable feature of the migration law in Spain is that it contains a
\end{abstract}

* The author would like to thank the reviewers for the constructive feedback received during peer review. Likewise, the author wants to thank the funding received from the Research Center for Development and Innovation of the Universidad Pontificia Bolivariana.This article is an outcome of the university project "Exploring new avenues in comparative immigration law that promote citizen coexistence and democratic values" (069C-04/18-37).

** Ph.D. in Human Rights, Democracy and International Justice. Research Coordinator at the School of Law and Political Sciences of the Universidad Pontificia Bolivariana, Medellín (Colombia). laura.garciaj@upb.edu.co ID http:// orcid.org/0000-0002-2896-4667 
regularisation mechanism for irregular immigrants that does not require them to have a visa in order to obtain the status of temporary residency. This mechanism is known as arraigo social (social ties). In these cases, access to regularity depends on the level of social integration that the immigrant can prove to have achieved. This article analyses the statistics on the use of this mechanism in Spain and discusses whether it could offer a path to asylum seekers looking for an official response after several years of waiting in the EU.

Key words: CEAS; asylum seekers; integration policy; integration measures; European Union.

Resumen: El debate sobre el alcance de las competencias de los Estados miembros de la UE sobre politicas de integración de inmigrantes llegó a su fin con el Tratado de Lisboa. Las instituciones europeas adoptaron un papel activo en integración pero sin imponer un enfoque comunitario. Cada país construyó así sus propias politicas, lo que derivó en una amplia diversidad de regulaciones entre las que destaca el modelo seguido en España por su enfoque particular del concepto de integración, aplicable aquí tanto a inmigrantes en situación regular como irregular. Como consecuencia directa de ello, una característica propia de la ley migratoria española es que contiene un mecanismo de regularización dirigido a los inmigrantes en situación administrativa irregular que no requiere ningún tipo de visado y por el que pueden acceder a un permiso de residencia temporal. Este mecanismo se conoce como arraigo social. En estos supuestos, el acceso a la regularidad depende fundamentalmente del nivel de integración social que el inmigrante demuestre haber alcanzado. Este artículo revisa las estadísticas de uso de este mecanismo de regularización en España y analiza si podría constituir una vía legal válida para los solicitantes de asilo que, tras varios años de espera en la Unión Europea, todavía no han recibido una resolución oficial.

Palabras clave: SECA; solicitantes de asilo; politicas de integración; medidas de integración; Unión Europea.

\section{INTRODUCTION}

After more than a decade, the European Migration System has proved to be ineffective in covering the needs of integration of hundreds of thousands of people who seek asylum, while trying to satisfy the security claims of the Member States. This is one 
reason that the European Union (EU) institutions have decided to reform the Common European Asylum System (CEAS), coupled with coordinating the procedures, requirements, and conditions for acceptance (Mayblin, 2019). One of the most remarkable aspects in the draft texts of the reform is the extension of the integration measures and conditions to asylum seekers and beneficiaries of international protection. Even if the reform is detailed, the new rules still fail to offer a solution for those asylum requests that are going to be denied after long waiting periods.

What happens to the people who are official asylum applicants and have not yet received a reply by the competent authority? They have been authorized to remain in the EU country that is dealing with their application, but in what conditions are they living? These asylum seekers are in an uncertain life situation, in a legal limbo, without receiving an answer from the CEAS (Heidenreich et al., 2019).

There is an administrative process in Spain intimately linked to integration policies that allows irregular immigrants to obtain a legal migration status, the so-called arraigo social. So, could this mechanism be a solution for the asylum seekers currently domiciled in Spain? What would happen if they decided to "waive" their applications and start the process to obtain a temporary residence permit?

The general goal of this research is to figure out if the arraigo social regularisation mechanism that is embedded in Spanish Migration Law could offer an alternative for those asylum seekers that are in such legal limbo. In order to achieve this general goal, the first specific objective is to review the legal texts that are pending approval by the EU Institutions, in order to clarify if the arraigo social mechanism fits for the asylum seekers that are waiting more than three years for a decision on their applications. The second specific objective is to analyse the national statistics of arraigo social in Spain as an existing regularisation mechanism in the Migration Law, throughout the period covered (2012-2018). This objective involves the management and interpretation of published data that is available on official websites. Furthermore, it involves the management of unpublished data that have been directly requested from the responsible public bodies in the Community of Madrid and in Catalonia. The data provided by Madrid and Catalonia have not been published by any public institution. The third specific objective is to determine, in view of the results of objectives one and two, whether this regularization mechanism is applicable to long-term 
asylum seekers who have applied in Spain and who are waiting here for an official response.

The methodology in order to achieve the first specific objective is based on the analysis of the legal documents related to the CEAR reform. In order to achieve the second objective, a business intelligence database model (Datamart) has been designed and implemented taking the statistics published by the State Secretariat for Migration. A datamart is a business tool used as a computing solution that consolidates data from different sources of an entity, institution, or business, whether from databases, flat files, or other systems, extracting, transforming, and storing them in a single information repository. The objective is to support decision-making in a business environment and centralize the data, interpret it, and give it added value for the benefit of the business, offering easy access and visualization for analysis by users. This methodology is completely applicable to quantitative research in the academic environment. By having the information centralized, integrated, and structured for analysis, it facilitates its interpretation.

In this project, the database allows us to extract, transform, and load the information to build visualization elements that facilitate the interconnection of the data, as well as its interpretation. To do this, ETL processes have been used, in addition to the loading processes of the collected historical information. In order to obtain the unpublished data for Madrid and Catalonia, previously arranged meetings were held with the officials responsible for the collection and custody of the data ${ }^{1}$.

In the first part of the article, the international and European context is briefly described to facilitate the approach to the subject in a chronological way. The second part deals with an important novelty contained in the CEAS reform, the integration measures for asylum seekers. The third part delves into the study of the particular mechanism for the regularization of immigrants contained in the Spanish law that is intimately linked to integration measures. The fourth part analyses the data obtained in relation to the proposed

1 In Catalonia: the responsible official in the Secretariat of Equality, Migrations, and Citizenship, belonging to the autonomous body with competences in labour and social affairs and family. In Madrid: the responsible official in General Directorate of Social Services and Social Innovation, belonging to the autonomous body with competences in social policies, families, equality, and birth. 
objectives and concludes that the regularization mechanism contained in the law could only be applied to long-term asylum seekers who submitted their asylum application in Spain.

\section{THE INTERNATIONAL AND EUROPEAN CONTEXT}

The United Nations General Assembly has included their concern for migrants and refugees in the latest fortnightly agenda. The 2030 Agenda for Sustainable Development contains the seventeen Sustainable Development Goals (SDG) they hope to achieve in this period. The tenth SDG is "Reduce inequality within and among countries" and its seventh goal aims to "Facilitate orderly, safe, regular and responsible migration and mobility of people, including through the implementation of planned and well-managed migration policies". To measure progress in achieving this goal, the number of countries that have implemented well-managed migration policies is established as an indicator. This is a fact that constitutes a breakthrough with respect to the previous fortnightly program, where barely a brief reference was made to international migrants, refugees, asylum seekers and internally displaced persons.

Following the path outlined in the 2030 Agenda, the UN General Assembly approved in September 2016 the New York Declaration for Refugees and Migrants from which derives the Global Compact for Safe, Orderly and Regular Migration and the Global Compact on Refugees, both adopted in 2018. For the purposes of this investigation, it should be noted that the latter refers to the local integration of refugees as a sovereign decision and an option that states can exercise guided by the obligations imposed on them by treaties and by the principles of human rights.

Contrary to what happens within the United Nations, for the EU the governing of migration flows has been one of the main topics on its agenda and strategic programs for over a decade, which has allowed this issue to reach an advanced stage. On May 13, 2015, the European Commission issued the European Agenda on Migration, in which immediate measures are proposed for dealing with the crisis in the Mediterranean. With regard to the long and medium terms, the Commission suggests guidelines in some political respects, such 
as reducing the incentives for irregular migration, improving border management, reforming the common asylum policy, and building a new policy on legal migration. These pillars set new priorities for integration policies and optimize the benefits of migration for the people involved as well as for the countries of origin.

The EU has historically been concerned in relation to the arrival of immigrants to its territory. However, such concern has grown in the last five years with the continuous and steady entrance of mixed flows of migrants and refugees, particularly those from Syria, Afghanistan and Venezuela ${ }^{2}$. The launching of the European Union Global Strategy in June 2016 proves this ${ }^{3}$. However, there has been a challenge not only with the management of such flows but also with the acceptance and accommodation of new arrivals into European societies and this has been a key aspect in the political agenda of the EU (Lund, 2019). In 2004, European institutions understood that immigration was not an isolated or temporary phenomenon; instead, it involved a considerable number of immigrants who ended up settling on a permanent basis. Therefore, since then, the integration of immigrants plays an important role in the EU's plans. Such priority was established when the Justice and Home Affairs Council adopted the Common Basic Principles in the framework of the Hague Programme.

One of the premises that justified these principles was the conviction that the success of the immigrants and their descendants' integration in the host society is an essential aspect of the management of migrations, and at the same time that migration policies may contribute to the success of the integration policy. However, one of

2 In 2019, there were 714,200 applications for international protection in the EU plus Norway and Switzerland, which is $13 \%$ more than the 634,700 applications received in 2018. During the previous years, there were 728,470 applications in 2017 and almost 1.3 million in 2016. Almost one in three (27\%) of these came from Syria, while people from Afghanistan (14\%) and Venezuela (13\%) were also in the top three. The number of Venezuelans rose by nearly 40 times in 2019 compared to 2018. See European Parliament News: 'Asylum and migration in the EU: facts and figures'. Updated 30/10/2020.

3 In contrast to the Global Strategy for the European Union's Foreign and Security Policy established in 2016 "Shared Vision, Common Action: A Stronger Europe," the migration policy failed to appear within the European Security Strategy in the period 2003-2015 "A Secure Europe in a Better World." However, thirteen years later, migration is one of the key points of the new global strategy (See European Council, 2016). 
the main errors in the formulation of the Community institutions' integration policies and instruments was to put aside asylum seekers, refugees, and beneficiaries of subsidiary protection (Klarenbeek, 2019). This situation began to be remedied with Regulation (EU) No 516/2014, which rules the Asylum, Migration and Integration Fund, which establishes the guidelines with regard to the effective integration of applicants and beneficiaries of international protection and of re-established refugees.

The Council understood that the effective management of migrations by each of the Member States would be in every one's interest, considering that the development and application of the integration policy is a fundamental responsibility of each of the states individually, more than the EU as a group (Sebastiani, 2017). The debate regarding the extent and level of Community competences in immigrants' integration policies was put on hold with the Treaty of Lisbon as, in the article 79(4) of the treaty, the European institutions were conferred an active role in integration but did not assume any specific competence that may anticipate a communitarization. As harmonization is excluded, each state was granted the liberty to rule according to its own interests, resulting in a diversity of models and approaches. Among these models, the one adopted by Spain stands out because it moves away to the European concept of integration (García-Juan, 2015).

The aim of this research is to analyse the arraigo social, which is a regularisation mechanism embedded in the migration legislation in Spain. It is an administrative procedure that allows irregular immigrants to obtain a temporary residence permit if they meet certain requirements. Consequently, the procedure also allows asylum seekers currently domiciled in Spain to voluntarily waive their asylum applications and start the process to obtain a temporary residence permit. This option may be available if some requirements, proving that the applicant has used their best efforts to be part of Spanish society, are fulfilled. The increased importance given to integration on the reforms set forth in the CEAS, as well as the extension of the integration measures to the asylum seekers, gives this administrative procedure special importance as a possible solution to thousands of refugees whose legal status is still uncertain. 


\section{INTEGRATION MEASURES WITHIN THE REFORM OF THE COMMON EUROPEAN ASYLUM SYSTEM}

The migration and refugee crisis suffered by some EU countries has revealed the need to review the legal reforms introduced in the CEAS during those years. Although one of the main purposes of the said modifications was to achieve further harmonization regarding procedures and requirements, in practice it has been demonstrated that considerable differences, which are still difficult to unify, continue to exist ${ }^{4}$. The main consequences are that "secondary movements" of refugees and asylum shopping continue to occur with regard to refugees and asylum seekers, which still hinder the efficient and organized management of international protection applications (Thielemann \& Armstrong, 2013).

In 2016, the European Commission encouraged a series of reforms, the objective of which is to harmonize the asylum procedures in all Member States by establishing common agreements to address the unequal implementation of the CEAS and the problems pertaining to the Dublin system. The ultimate goal is to offer a law not only suitable to any third-country national who needs international protection but also to ensure the fulfillment of the principle of non-refoulement (Rossi, 2017). European institutions still conducting negotiations to make the said reforms, although all movements were practically frozen in February $2019^{5}$. Additionally, we are now unsure of how the COVID-19 pandemic that is affecting the whole world will evolve, which without a doubt, will deeply affect the proposed reforms. In fact, the most recent

4 The CEAS is characterized by the Member States' difference in treatment regarding asylum seekers and asylum applications. Some of these differences comprise the terms for administrative proceedings, reception conditions, term of duration of the residence permits granted, and unequal access to integration programs. See Valenta et al., 2019.

5 The three texts under discussion are: 1- Proposal for a Directive of the European Parliament and of the Council laying down standards for the reception of applicants for international protection [COM(2016) 465 final]; 2- Proposal for a Regulation of the European Parliament and of the Council on standards for the qualification of third-country nationals or stateless persons as beneficiaries of international protection, [COM(2016) 466 final]; 3- Proposal for a Regulation of the European Parliament and of the Council establishing a common procedure for international protection in the Union and repealing Directive 2013/32/ EU [COM(2016) 467 final]. 
communication presented by the European Commission on this matter is the New Pact on Migration and Asylum, launched in the midst of the pandemic on 23 September. If we look at the spirit of this document, it can be deduced that the European approach is still rather favourable to expulsion as a measure applicable to people who are illegally in an EU state, instead of the fine, or any other measure that implies, directly or indirectly, a certain "tolerance" (European Commission, 2020).

If we look at Chart 1 we see that the peak of asylum seekers for the first time in the European Union was reached in 2015 and 2016, precisely coinciding with the drive for CEAS reform.

\section{CHART 1}

FIRST TIME ASYLUM APPLICANTS IN EU (28 MEMBER STATES)

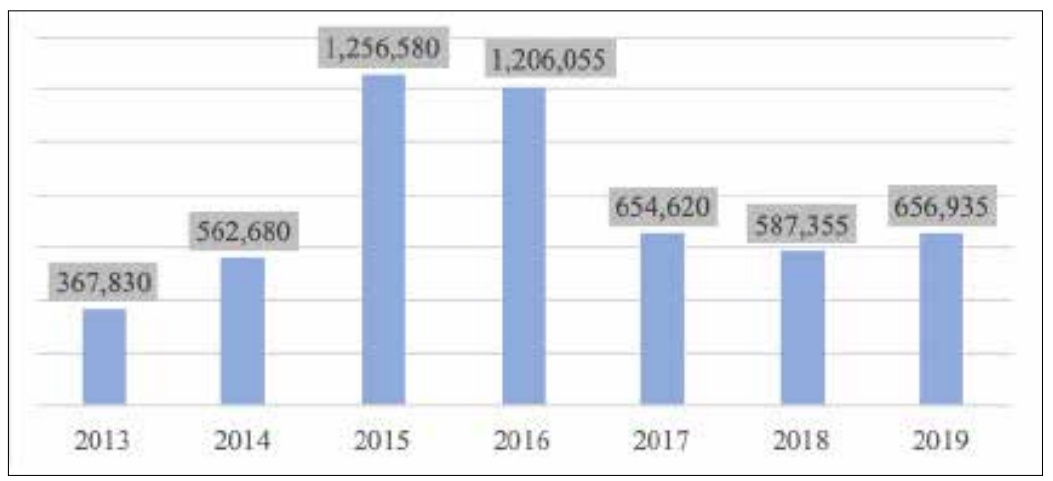

Source: own elaboration based on Eurostat data.

In the meantime, hundreds of thousands of asylum seekers continue to look forward to an official resolution that clarifies their legal status. These are people whose applications are regulated by the CEAS currently in force. Chart 2 shows the number of applications that have been pending at the end of each month from April to December 2019. 
Chart 2

\section{PERSONS SUBJECT OF ASYLUM APPLICATIONS PENDING AT THE END OF THE MONTH IN EU (28 MEMBER STATES)}

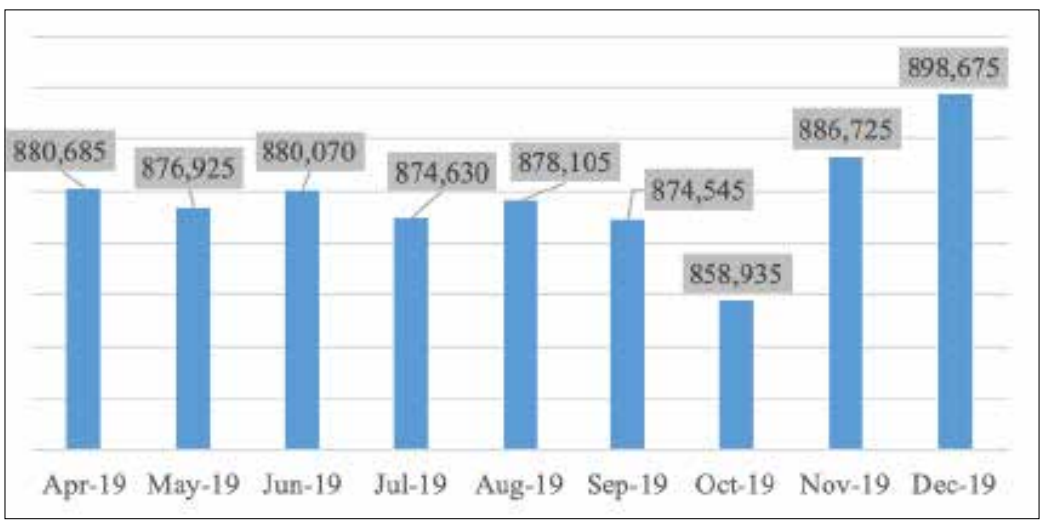

Source: own elaboration based on Eurostat data.

In view of the high figures in Chart 2 we must ask ourselves, what happens with the people who have submitted an official asylum request but have not yet received a reply from the competent authority? They have been authorized to remain in the country of the EU that is dealing with their application but in what conditions are they living? Can adults work legally in the labour market? Do children have access to regular education systems? Do they have access to the reception and integration programs offered by the different public administrations and other private entities? Are they able to waive their asylum application and apply for a resident permit?

For a better contextualization from a quantitative point of view, the following table shows the total of the official responses issued by the competent asylum bodies of all EU Member States, both positive and negative, between 2013 and 2019.

Not all of the figures included in positive resolutions as shown in the Table 1 have to do with the refugee status established in the Geneva Convention. In fact, in the majority of these cases, the applicant was granted humanitarian status or subsidiary protection status. 
TABLE 1

\section{FINAL DECISIONS ON ASYLUM APPLICATIONS (EU 28 MEMBER)}

\begin{tabular}{|c|c|c|c|}
\hline Year & Rejected & Positive & TOTAL \\
\hline 2019 & $154,760(64 \%)$ & $86,740(36 \%)$ & 241,500 \\
\hline 2018 & $190,950(62 \%)$ & $117,935(38 \%)$ & 308,885 \\
\hline 2017 & $186,240(66 \%)$ & $95,310(34 \%)$ & 281,550 \\
\hline 2016 & $188,355(82 \%)$ & $42,630(18 \%)$ & 230,985 \\
\hline 2015 & $152,900(85 \%)$ & $26,400(15 \%)$ & 179,300 \\
\hline 2014 & $109,835(81 \%)$ & $26,195(19 \%)$ & 136,030 \\
\hline 2013 & $109,970(82 \%)$ & $24,675(18 \%)$ & 134,645 \\
\hline
\end{tabular}

Source: own elaboration based on Eurostat data.

Those asylum seekers that still have not received a positive resolution are in an uncertain life situation, in a legal limbo (Chetail, 2016). The expected CEAS reforms emphasize the need of increasing the applicants' integration opportunities not only for those already having refugee status or subsidiary protection but also for those cases where there is a possibility of their applications being accepted. To achieve this, it is suggested that the asylum applicants should be able to work and obtain an income as soon as possible, even while their applications are being processed (Rizcallah, 2019). In the following paragraphs, we go through the way in which integration measures and conditions have been addressed in the reforms that are currently subject to negotiation in the EU's main institutions. Such integration measures and requirements comprise courses, tests, and other kinds of examinations in which the level of mastery over the language of the host community is assessed, as well as knowledge regarding regulations, history, customs, and principles of the Member State. In some European countries, these are called cultural integration courses (Niejenhuisa, Ottenb \& Flachea, 2018).

Although both terms are used indistinctively in the different translations on Community rules, here the expression "integration requirements" will be used to refer to specific compulsory requirements that the Member States may demand (before leaving the country of origin or upon arrival) of the relatives with whom reunification has 
been sought. They also refer to the compulsory requirements that may be stipulated to renew the temporary residence permit or to acquire a permanent one (called "long-term residence permit") in order to acquire the nationality of the country of residence or to retain the benefit of the material conditions for its acceptance. Here the term "integration measures" will be used when referring to agreements, programs, circuits, or devices in which migrants voluntarily participate (economic immigrants, refugees, asylum applicants, and beneficiaries of subsidiary protection) to access specific rights, renew their work and residence permits, or to modify their migration status, among others.

The main EU directives that refer to the integration measures and requirements are the Council Directive on the right to family reunification and the Council Directive concerning the status of third-country nationals who are long-term residents. The scope of application of the former comprises both resident legal immigrants as well as beneficiaries of refugee status, although in this second scenario the regulation does not allow the imposition of integration conditions prior to departure. The second directive is applied to resident legal immigrants in the Member States of the EU but not to the applicants or beneficiaries of international protection. Accordingly, these 2003 Directives are limited with regard to the impact they can have on integration when considering other special needs, specifically the challenges of integration to which the beneficiaries of international protection are faced with to be guaranteed the effective exercise of their rights and benefits. Kees Groenendijk (2006) stated that "the way in which these Community law instruments will be implemented by the member states in their national law, will offer a good indication of the extent to which member states seriously do want to further the integration of immigrants in their societies".

At this point, it is necessary to look at the Directives of 2011 and 2013 of the European Parliament and of the Council that regulate some issues concerning beneficiaries of international protection (European Parliament, 2011, 2013a and 2013b). While Directives 2013/32/EU and 2013/33/EU make no mention of integration measures or requirements, Directive 2011/95/EU simply establishes that Member States have to guarantee their international protection beneficiaries access to integration programs that they consider fit with regard to specific needs but leaving total freedom in relation to its structure. It should be noted that said access is limited to those 
who are already beneficiaries of the refugee or subsidiary protection status $^{6}$. None of those three directives contains a definition of integration. Still, the Directive 2011/95/EU refers to Common Basic Principles of Integration which state that "Integration is a dynamic, two-way process of mutual accommodation by all immigrants and residents of Member States".

Unlike these Directives of 2011 and 2013, in the reformed texts of 2016 the integration of international protection beneficiaries is a key and central issue in the entire regulation. Accordingly, such reforms would amend what is referenced above regarding the historical omission of this group in the Community acquis with regard to integration, as well as to the minor importance given to integration in the European Community law enforced regarding asylum and refuge. The texts being discussed deal with "effective integration and participation of all, refugees or legal migrants".

The expected reforms emphasize the need of increasing the applicants' integration perspectives not only for those who already have refugee status or subsidiary protection but also for those cases where there is a possibility of their applications being accepted. To achieve this, it is suggested that asylum applicants should be able to work and obtain an income as soon as possible even while their applications are being processed. Also, compulsory integration measures are mentioned for the first time, the nonfulfillment of which may lead to benefit substitution or reduction, or to the withdrawal of the reception conditions.

The proposal establishing the requirements for the acknowledgment of international protection considers it to be essential for Member States to promote the integration of its beneficiaries into their societies. At the same time, it states the scale and scope of the rights and obligations and offers incentives for its active integration. In addition, it also allows the 27 members to grant some kind of social assistance. All these benefits may come with the condition of the effective participation of these beneficiaries in the integration measures in accordance with the Action Plan on the integration of third-country nationals (European Commission, 2016). This means that Member States are permitted to decide whether their participation in the measures is compulsory or not. When dealing with integration, the said action plan refers exclusively to immigrants

6 See article 34 of the Directive 2011/95/EU. 
and refugees from third countries who are legally residing in the $\mathrm{EU}^{7}$.

Another relevant aspect of the CEAS reform is the possibility for those who have been given refugee status or subsidiary protection but for whatever reason, no longer enjoy this status, to have three months to request another legal status. For example, as a resident immigrant for working reasons. It is important to highlight that such a possibility is only offered to those who at some time benefited from international protection, but it does not include those who still waiting for an administrative resolution as asylum seekers. In view of this possibility, the question is mandatory: if those who were once beneficiaries of international protection (but are no longer) can apply for a residence permit without obtaining a visa, what about those asylum seekers who have remained a long time in the EU territory waiting for an official response and having participated in the integration programs? Why cannot they do the same?

Spanish migration law de facto grants this possibility to asylum seekers through the procedure of arraigo social. The law does not expressly refer to asylum seekers when it regulates this legal figure, but neither does it expressly excludes them. This means that the asylum applicants who have not yet received their official response but meet all the requirements to apply for a work and residence permit for reasons of arraigo social could start this process without major problems.

\section{THE REGULARISATION MECHANISM IN THE SPANISH LAW}

In the Community acquis, humanitarian residency permits are meant for specific categories of people who are not included in the concept of international protection. It is another way of recognizing the needs of migrants that fail to meet the requirements attendant to a request for the right to asylum. For example, victims of human trafficking or domestic violence. The Community rules establish that once a humanitarian visa has been issued and the third-country national has entered into the territory of the host country within the EU, this person may file an asylum request or some other kind of residence request, such as the humanitarian residence. From this

7 Integration measures can be language and civil integration courses, professional formation courses, and similar courses related to employment. 
moment onward, the said request is governed by the corresponding internal legal system and is subject to the requirements and formalities this legal system has (European Parliament, 2014).

It needs to be emphasised that article 31(3) of the Spanish Migration Act, called "Act 4/2000 on the rights and freedoms of foreigners in Spain and their social integration" (hereinafter LODYLE, for its Spanish acronym), extends the assumptions contained in articles 19(4) and 25(1) of the Visa Code Regulation and exempts the obligation to present a visa to those in a situation of arraigo, humanitarian reasons, collaboration with the Justice or other exceptional circumstances that are determined by regulation (Spanish State, 2000).

Article 31(3) of the LODYLE establishes that a temporary residence permit may be granted on the grounds of social ties (arraigo), as well as for humanitarian reasons, collaboration with authorities, or other exceptional circumstances. In line with the said provision, the Decree regulating the Act's implementation (Royal Decree 557/2011) contains in its Title V a series of precepts that are in reference to those other assumptions that describe the EU rules. The said section is titled "Temporary residence due to exceptional circumstances" and comprises the following cases: a) those that have the possibility of requesting a temporary residence permit for reasons of social ties, international protection, humanitarian reasons, collaboration with authorities, national security or public interest; b) women from foreign countries who are victims of gender violence; c) those who collaborate with authorities in the fight against organized crime; and d) human trafficking victims from foreign countries (Spanish State, 2011) ${ }^{8}$.

This section of the research is dedicated to the so-called arraigo social, a legal framework in the Spanish legal system with some special features (as the exemption of visa), making it unique among the others in the $\mathrm{EU}^{9}$. It is a regularisation mechanism widely used in Spain that could be relevant to asylum seekers if the foreseen reforms by SECA prosper and integration measures are open to this group. This mechanism would provide, at least in Spain, a feasible

8 See article 124 of the Royal Decree 557/2011.

9 It is important to stress that Spain but some other EU Member States regularise irregular migrants through their own regularisation mechanisms. These mechanisms are part of the regular migratory policy framework and are thus permanent measures. See further information in Baldwin-Edwards, M. \& Kraler, 2009. 
solution to the situation of legal limbo in which a large number of these people find themselves.

This regularisation mechanism was designed for immigrants who were in an irregular administrative situation in Spain and could not meet the requirements attendant to requesting international protection or a residence permit for humanitarian reasons but whose situation was exceptional (Aguilera, 2006). This turns the arraigo social mechanism into a specialty of Spanish law, which contains provisions related to the integration of irregular immigrants (Carbajal, 2012).

To contextualize the upsurge of this idea of social ties, here is a brief summary of its background information. The concept of arraigo was introduced for the first time in the year 2003 as a means for third-country nationals to obtain temporary residence, with the second modification to the LODYLE (Spanish State, 2003) ${ }^{10}$. In that year, Spain was the EU country with the highest level of net immigration (Source: Eurostat), which is why it was urgent to find a mechanism that could progressively relieve the constantly rising number of irregular immigrants in the territory.

The 2004 Royal Decree developing this Act (which has already been abrogated) distinguished three different types of ties that were later on branded as arraigo laboral (work ties), arraigo familiar (family ties), and arraigo social (social ties). These three types of arraigo remained unchanged in the 2011 regulation, which is still in force. According to this regulation, it is possible to obtain temporary residence by means of work ties if the applicant can prove continual undeclared work in Spain for a minimum period of two years and there is a final judgment delivered against their employer. The same occurs with the parents of a Spanish minor if they fulfil some requirements in the situation of family ties.

The particular aspect of arraigo social is that this legal avenue allows the granting of a temporary residence permit to nonEU nationals illegally staying in Spain who meet the following requirements: 1- Proving three continual years of permanence in Spain (having stayed under an irregular administrative situation); 2- Not having a criminal record; 3- Having a pre-contract of employment for a term of at least one year; and 4- Proving certain ties with Spain, either by means of family bonds, bonds with other

\footnotetext{
10 See article 1, provision 12 of the Act 14/2003.
} 
foreign residents, or by means of a social insertion report issued by the City Hall corresponding to that person's permanent address.

As noted in section 3, it is important to stress that the regulation does not expressly exclude people with a pending request for asylum. In addition, the regulation makes reference to the foreigner's "ties report proving social insertion" and stipulates that the said report shall have to include a list with the "integration efforts by means of programs addressing social, working and cultural insertion" (Rinken et al., 2016). The existence of this regularisation mechanism in the Spanish legislation forces the different public administration entities to adopt policies that enable and favour the fulfilment of the requirement of a social insertion report. This is the main reason why integration policies in Spain are addressed not only to legally residing third-country nationals but also to those in an irregular administrative situation (Espinola, 2007).

It must be pointed out that arraigo social is still one of the most important ways of obtaining the administrative regularity in Spain. Furthermore, these residence permits granted by means of the ties procedure also grant a work permit to both independent workers and employees, which allows the foreigner to access the local market. This legal path to end their illegal presence is totally in line with the provision contained in article 6(4) of the Directive on common standards for returning illegally staying third-country nationals (European Parliament, 2008).

We will see in the next section that thousands of immigrants receive a temporary residence permit in Spain every year for reasons of social ties regardless of their migration status. In reality, both immigrants in an irregular situation and asylum seekers with more than three years of permanence in Spain may apply for this type of permit. As for asylum applicants, they may initiate the procedure by means of arraigo social by submitting, along with the requested documentation, a statement in which the applicant expressly desists from his/her asylum process. This document is the only thing differentiating their administrative procedure from those initiated by non-EU immigrants searching for a temporary permit by means of ties.

To fulfil the rest of the arraigo social requirements that Spanish legislation demands, the asylum applicant who has decided to give up their asylum-seeker status must also prove that they have remained in Spain for three consecutive years by submitting a legal registration certificate. Article 6 of the LODYLE obliges city halls to register 
foreigners in the Municipal Register of Inhabitants (better known as padrón municipal) recording a permanent address, meaning that the most usual scenario is that the applicants for arraigo social can easily prove their permanence in Spain. Likewise, the interested party must have a pre-contract of employment for a term of one year, have no criminal records, and show that they have established ties by means of a social insertion report issued by the City Hall corresponding to their neighbourhood. This report must prove the individuals' integration efforts by means of their participation in programs addressing social, labour and cultural insertion.

In Spain, thousands of third-country nationals participate each year in language, culture, and history courses, joint with courses about national, and EU values that are run by local city halls or by other public and private entities. These are integration measures (cultural integration courses) that are not obligatory in this country but are ones that immigrants interested in receiving a positive report from the municipal government frequently attend (Moya, 2008). These reports are meticulously structured, including one or several personal interviews in which specific aspects and needs of the case at hand are dealt with, independently from the applicant's nationality; their condition; migration status; or the countries they have crossed to get to Spain. What is relevant is the individual's life story and real efforts made to integrate into the society in which they have decided to settle.

A report from 2018 on the reception system and the integration conditions of the asylum seekers in Spain points out that, in general, the waiting time for a resolution, which is usually a dismissal, is three years. This rejection means that these individuals are not granted provisional residence or a work permit and that they are obligatorily made to exit the country, which means "an interruption in the development of the path of integration after months or years of being part of Spanish society." This leads to the individuals losing their jobs and lease agreement as well as their social assistance. All of the aforementioned invalidates the efforts and public investments made to boost their effective integration into society. The report confirms that in view of this situation, "many asylum seekers, the applications from whose are usually discarded by means of their nationality, wait for three years and then go for social ties (arraigo social) as the principal means to obtain residence in Spain" (Iglesias et al., 2018).

As has been shown, the arraigo social legal mechanism acknowledges the fact that the personal circumstances affect not 
only irregular immigrants but also the asylum applicants who have decided to give up their asylum-seeker status. However, in the current Spanish reception system, integration measures are neither adapted nor defined according to the needs of this collective as they have been almost exclusively designed for economic immigrants since being implemented almost a decade ago. As we have seen in the previous section, the CEAS reform is expected to extend integration measures and make them more comprehensive for those with a pending asylum application, so that this reform can be beneficial for asylum seekers. Consequently, this might help them to access the social, working, and cultural programs that allow them to obtain the ties report proving their social insertion.

Chart 3 shows that, contrary to what is happening in the rest of the EU, the number of asylum seekers continues to grow exponentially in Spain. In 2019 Spain received 115,175 applications, leaving it third behind Germany $(142,450)$ and France $(119,915)$. In 2020 , Spain is leading the rankings due to an increase in requests from Venezuelan and Colombian people (Eurostat, 2020).

CHART 3

FIRST TIME ASYLUM APPLICANTS IN SPAIN

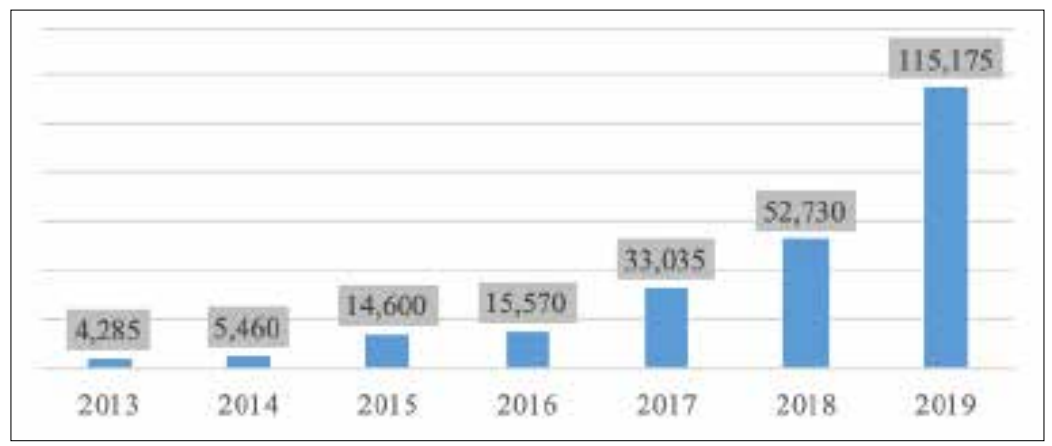

Source: own elaboration based on Eurostat data.

\section{THE STATISTICS OF THE MECHANISM OF ARRAIGO SOCIAL IN SPAIN}

The data that appears in the following charts referring to the flow of authorizations, both by means of initial work and by means of 
social ties, have been obtained from the statistical reports published each year by the State Secretariat for Migration (attached to the current Ministry of Inclusion, Social Security and Migration $)^{11}$. This data has been processed using a business intelligence database model (Datamart) specifically designed for achieving the second specific objective of this project. This database has been built by taking the referred statistics and has allowed us to extract, transform and load this information to build visualization elements that facilitate the interconnection of the data, as well as its interpretation. To do this, ETL processes have been used, in addition to the loading processes of the collected historical information ${ }^{12}$.

The statistical data on the number of integration effort reports required and issued has been provided by the public officials mentioned above from the competent bodies in the field of integration in both Catalonia and the Community of Madrid. These two autonomous regions have been selected because they represent $45 \%$ of the total authorizations by means of arraigo social granted in Spain during the sample period (2012-2018). This means that the conclusions that will be reached by reviewing the statistics in these two territories are sufficiently representative of the total.

Chart 4 shows the number of authorizations by means of initial work and by means of ties (social, family, and work ties) granted between 2012 and 2018 in Spain. We have taken 2012 as the first reference year because it was then that the reports of social insertion began to be issued, since this is information that we must combine with statistical data on the number of authorizations granted.

The Spanish government does not publish the data disaggregating by authorizations by means of arraigo social, arraigo familiar and arraigo laboral, although the authorizations granted by means of social ties represent $80 \%$ within this group. Those by means of family ties represent $18.7 \%$, and those by means of labour ties represent $1.3 \%$, as shown in Chart 5 .

11 See web site http://extranjeros.mitramiss.gob.es/es/Estadisticas/operaciones/flujos-autorizacion/index.html Accessed in August 2020.

12 ETL is the process by which data is extracted from data sources that are not optimized for analytics, and moved to a central host which is. The exact steps in that process might differ from one ETL tool to the next, but the result is the same. At its most basic, the ETL process encompasses data extraction, transformation, and loading. 
Chart 4

FLOW OF AUTHORIZATIONS BY TYPE OF AUTHORIZATION (TOTAL FOR SPAIN)

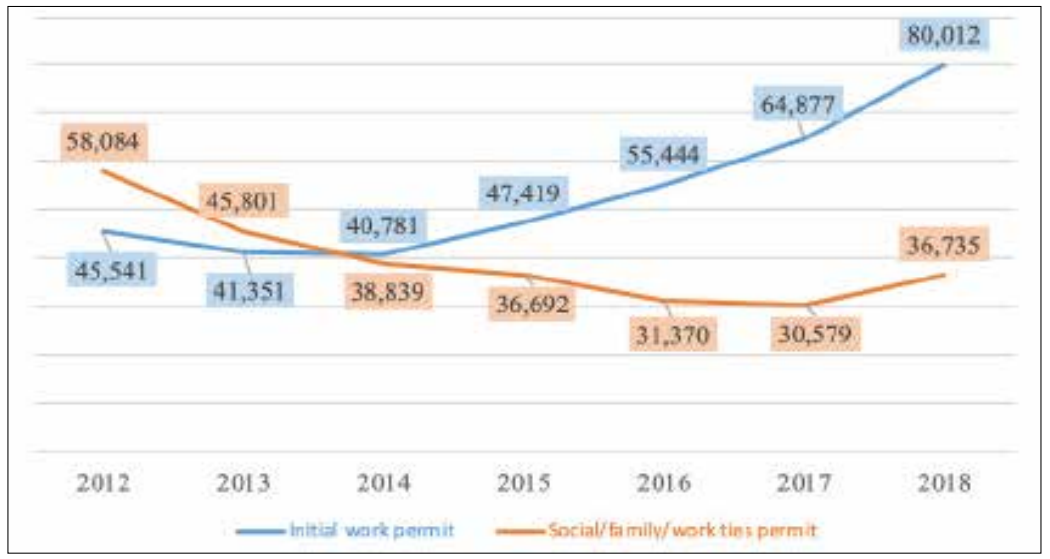

Source: own elaboration based on Permanent Observatory of Immigration data.

\section{CHART 5}

\section{FLOW OF AUTHORIZATIONS BY MEANS OF TIES (TOTAL FOR SPAIN)}

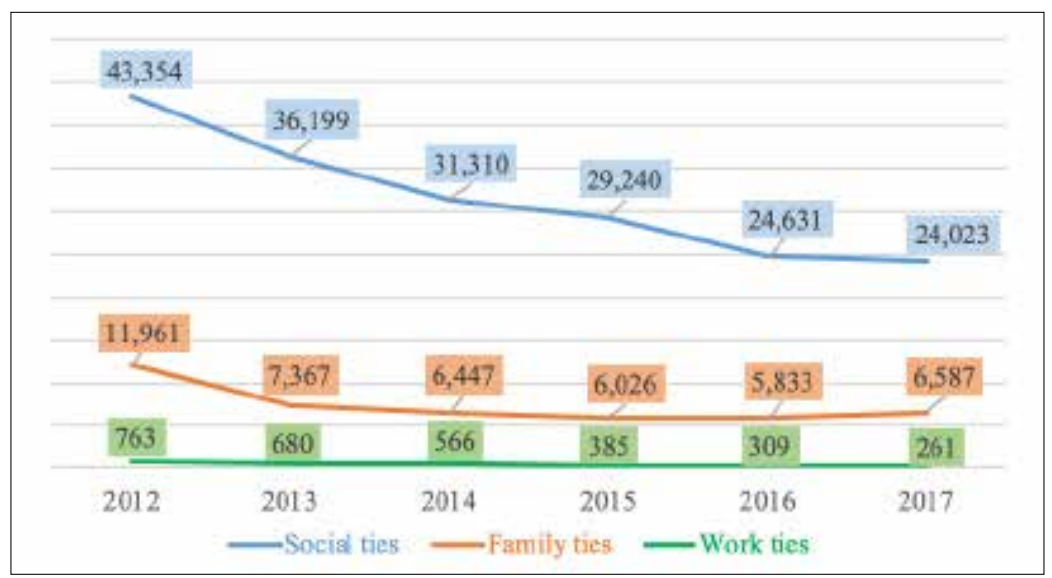

Source: own elaboration based on Permanent Observatory of Immigration data (unpublished). The small mismatches between the data shown in Chart 4 and those shown in Chart 5 are due to differences in interpretation in the reason for granting the authorization, which forces some specific cases to be moved to other groups. 
Four autonomous regions total $70 \%$ of the authorizations granted in Spain by means of ties, namely Community of Madrid, Catalonia, Andalusia and the Valencian Community in this order. It can be seen in Chart 6 that the general trend from 2012 to 2018 was downward in the four regions. However, a general increase can be observed in 2018. Madrid is the autonomous region that shows a sharper decrease between 2012 and 2014 in the number of authorizations granted by means of ties, while in the other regions the decrease is progressive until 2017.

CHART 6

AUTHORIZATIONS GRANTED BY MEANS OF TIES

(MAIN AUTONOMOUS REGIONS)

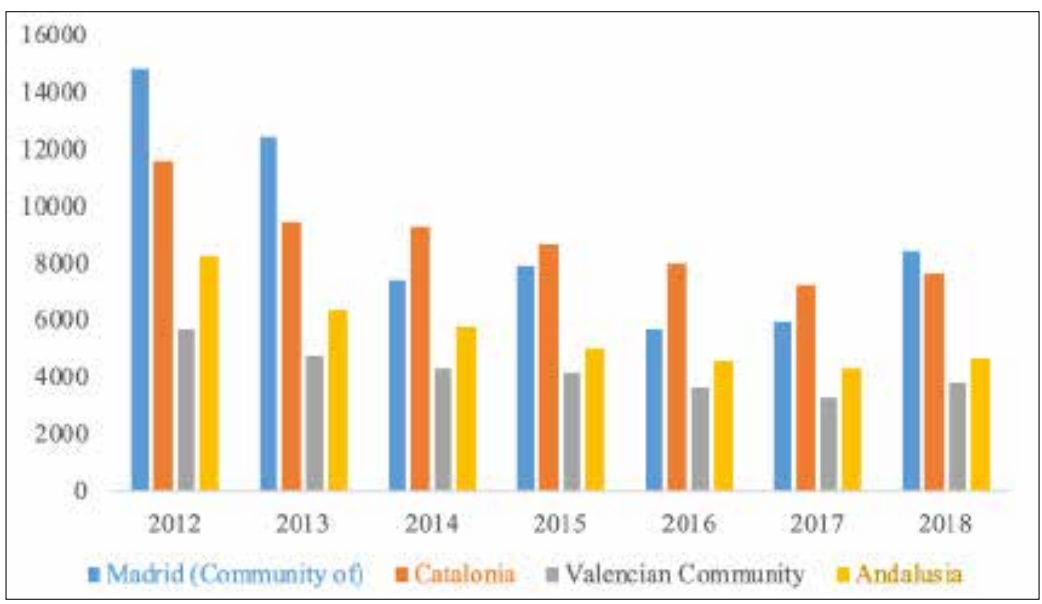

Source: own elaboration based on Permanent Observatory of Immigration data.

The central administration, through their Government Delegations and Immigration Offices (attached to the current Ministry of Territorial Policy and Public Function), receives the applications and processes the temporary residence authorizations by means of ties. The first step requires that the local council carry out an interview with the applicant. They request and receive the necessary documentation from the applicant and make a draft of the integration report. The local council then sends the draft 
telematically to the regional autonomous body which, in turn, reviews and validates the information and decides if the applicant should receive a favourable report. They then send the final report to the Immigration Office who are responsible to deliver the final approval or denial. The process only functions effectively when all three bodies work closely together and in the correct order.

In some territories, such as the Community of Madrid, the autonomous government has a network of third-sector organizations with which it has signed an agreement for the implementation and management of civic integration and language learning programs. Attendance in these programs is one of the aspects that immigrants must prove in order for the integration report to be favourable ${ }^{13}$.

\section{Chart 7}

\section{INTEGRATION REPORTS REQUESTED AND INTEGRATION REPORTS WITH A FAVOURABLE OUTCOME}

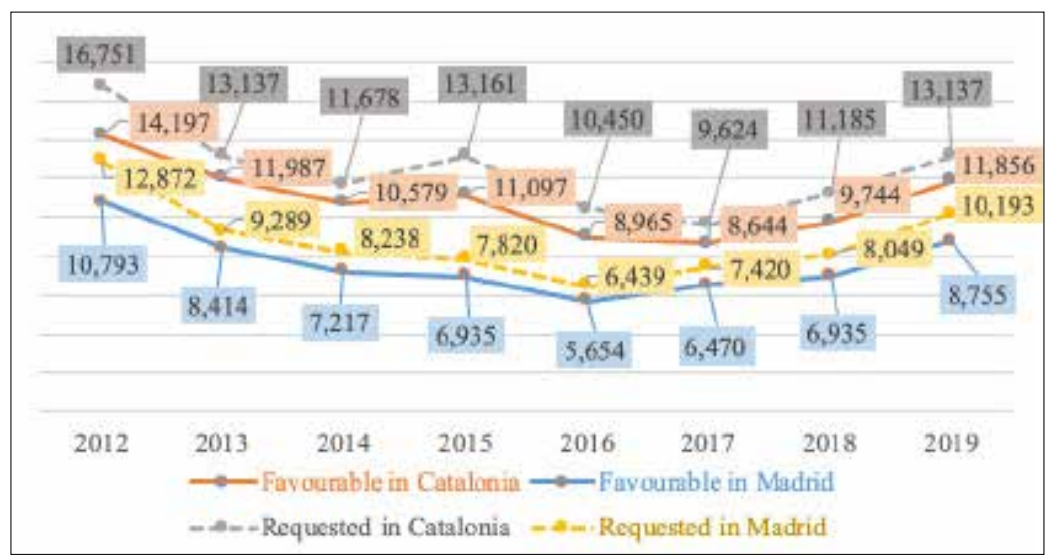

Source: own elaboration based on data provided by the autonomous bodies with responsibility for matters of integration reports (unpublished).

Chart 7 displays both the total number of integration reports requested by immigrants and those with a favourable outcome in Madrid and Catalonia between 2012 and 2019. It can be seen that

13 See web site https://www.comunidad.madrid/servicios/asuntos-sociales/ centros-participacion-e-integracion-inmigrantes Accessed in August 2020. 
the progress of both lines in the two autonomous regions takes place in parallel throughout the period. At the same time, the number of integration reports requested is higher in Catalonia than in Madrid. Catalonia leads the ranking, despite the intense unrest caused by the independence issue that took place during 2019. In fact, in the last three years, there has been a progressive increase in requests for integration reports, both in Catalonia and Madrid.

CHART 8

AUTHORIZATIONS GRANTED BY MEANS OF TIES AND INTEGRATION REPORTS WITH A FAVOURABLE OUTCOME (2012-2018)

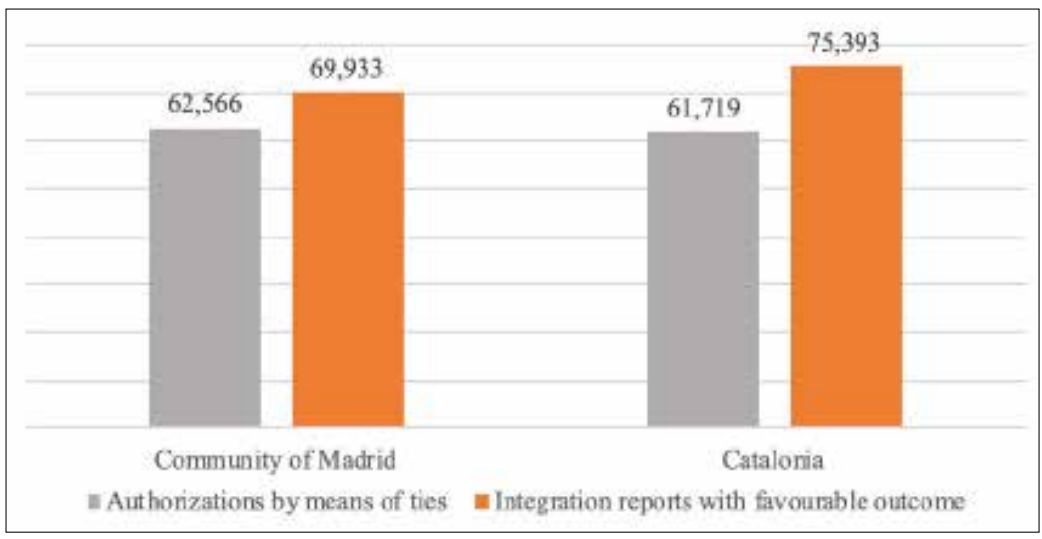

Source: own elaboration based on Permanent Observatory of Immigration data and data provided by the autonomous bodies with responsibility for matters of integration reports (unpublished).

The columns in Chart 8 show a slight gap between the authorizations granted by the Immigration Offices (at the national level) and the Integration Reports with favourable results issued by the autonomous bodies with responsibility for immigrant integration. This small difference shows that both administrative levels are coordinated in their functions and resolve requests practically in parallel. Such coordination between the national and autonomous level of the responsible public bodies implies that irregular immigrants who obtain a favourable integration report 
from the autonomous body, when they subsequently apply for a residence authorization by means of ties are granted with these permits in almost all cases. In short, the responsible authority at the national level for granting residence permits takes into account the integration reports issued by the competent body at the regional level. It is observed that the difference between the two columns compared is less in Madrid than in Catalonia, which may mean that the coordination between the two administrative levels is more significant in the capital of the country. However, these differences are not determinative for our research.

These statistics include the integration reports requested by former asylum seekers, as these figures are not disaggregated. Both the authority responsible for issuing residence permits and the body responsible for issuing integration reports do not break down the information regarding asylum seekers who find themselves in this situation. As noted above, the law does not prevent asylum seekers from requesting an integration report. If they obtain a favourable integration report, nothing prevents them from subsequently applying for a residence authorization by means of arraigo social.

The problem is that many of them do not participate in the civic integration programs offered by town councils, autonomous entities, and other private entities. In some cases, it is due to misinformation because they do not know about the existence of these programs. However, in other cases, it is because civic training activities have been designed and are being delivered only for economic immigrants and not for asylum seekers. This is a public policy problem that needs to be urgently addressed in Spain (Iglesias et al., 2018).

If we look at Chart 9, we can get an idea of the large number of asylum seekers whose application remains unanswered month by month in Spain. As we have seen, a large number of them could benefit from the arraigo social. Unfortunately, it is impossible to know exactly how many applicants are benefiting from this regularization mechanism, since, as we have seen, the statistics are not disaggregated. As a consequence, it is also not possible to determine precisely the number of asylum seekers who could benefit in the future. 


\section{CHART 9}

\section{PERSONS SUBJECT OF PENDING ASYLUM APPLICATIONS AT THE END OF THE MONTH IN SPAIN}

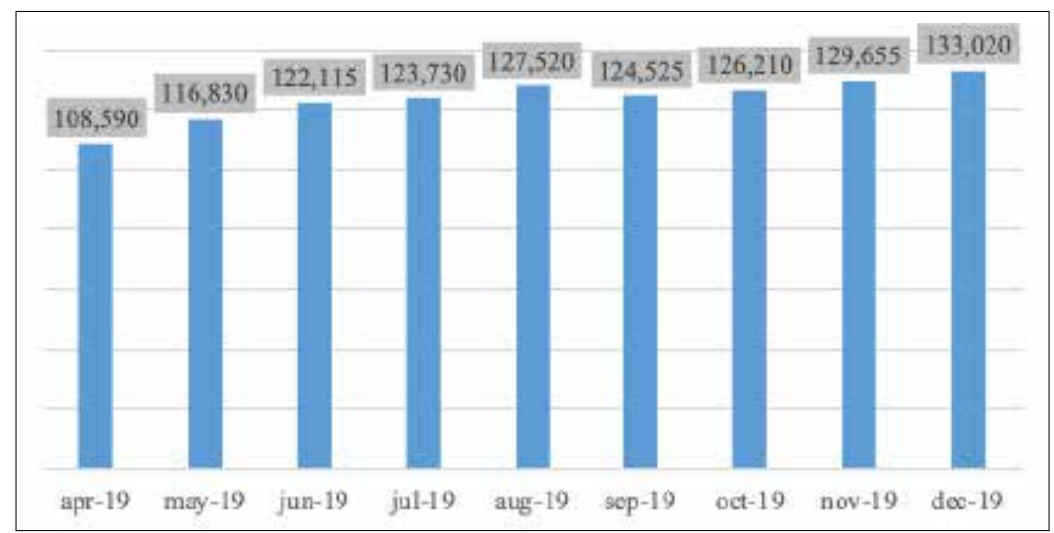

Source: own elaboration based on Eurostat data.

\section{CONCLUSIONS}

The CEAS reforms do not offer a solution to asylum applicants in legal limbo. No mechanism has been developed for solving the problem of hundreds of thousands of people who find themselves in EU territory without a defined legal statute, without the possibility of working legally, and without a clear idea of what their rights and obligations are. Nevertheless, the increased importance given to integration, coupled with the extension of the integration measures to asylum seekers, gives the arraigo social process special importance as a possible solution to thousands of asylum seekers whose legal status is still at an uncertain point.

In response to the question we asked ourselves at the beginning, it can be concluded that arraigo social is working in Spain for the former asylum seekers, although it is impossible to know how many exactly benefit each year from this mechanism. In this country, this regularisation mechanism provides a feasible solution to overcome the uncertain and hopeless situation in which a large part of these people currently find themselves. At EU level, such a mechanism could offer an alternative for asylum seekers that are still waiting for an official response after three years. The CEAS reform provides an 
exciting starting point in this regard. The draft documents make it possible that those who have been given refugee status or subsidiary protection, but for whatever reason, no longer enjoy this status, to have three months to request another legal status. Why not open this possibility also to asylum seekers who prove they have participated in the integration programs that the CEAS reform itself proposes?

At the same time that I write these lines (August 2020), the European Commission has launched a massive survey on its immigrant integration policies. This survey is mainly aimed at immigrants and asylum seekers, since their participation in the construction of the new EU strategy on integration is considered essential. Let's hope that this time the European institutions open up to disruptive solutions that seriously tackle a problem that is still pending.

\section{REFERENCES}

Aguilera Izquierdo, R. (2006). El acceso de los inmigrantes irregulares al mercado de trabajo: los procesos de regularizacion extraordinaria y el arraigo social y laboral. Revista del Ministerio de Trabajo y Asuntos Sociales, 63, 175-195.

Albertí Rovira, E. (2010). Concepto y función del Estatuto de Autonomía en la Sentencia 31/2010, de 28 de junio, sobre el Estatuto de Autonomía de Cataluña. Revista Catalana de Dret Públic, Edición especial Sentència sobre l'Estatut, 81-85. Retrieved from http://revistes.eapc.gencat.cat/ index.php/rcdp/article/view/146

Baldwin-Edwards, M., \& Kraler, A. (eds.) (2009). REGINE. Regularisations in Europe. Amsterdam: Pallas Publications. Retrieved from http:// research.icmpd.org/projects/migration-governance/regine/

Barceló i Serramalera, M. (2010). La doctrina de la Sentencia 31/2010 sobre la definición estatutaria de las categorías competenciales. Revista Catalana de Dret Públic, Edición especial Sentència sobre l'Estatut, 251257. Retrieved from http://revistes.eapc.gencat.cat/index.php/rcdp/ article/view/155

Carbajal, P. (2012). El arraigo como circunstancia excepcional para poder residir y trabajar legalmente en España. Revista de Derecho Migratorio y Extranjería, 29, 55-85.

Chetail, V. (2016). The Common European Asylum System: Bric-à-brac or System?. In V. Chetail, P. De Bruycker and F. Maiani (Eds.), Reforming the Common European Asylum System. The New European Refugee Law (pp. 1-38). Brill. https://doi.org/10.1163/9789004308664_002 
Espinola, G. (2007). Buscando Arraigo. Inmigrantes y vivienda: otro modo de exclusión., Universitas: Revista de Filosofía, Derecho y Politica, 6, 91106. Retrieved from http://universitas.idhbc.es/n06/06-06.pdf

European Commission. (2020). Communication from the Commission to the European Parliament, the Council, the European Economic and Social Committee and the Committee of the Regions 'New Pact on Migration and Asylum' [COM(2020) 609 final].

European Commission. (2016). Communication from the Commission to the European Parliament, the Council, the European Economic and Social Committee and the Committee of The Regions 'Action Plan on the integration of third country nationals' [COM(2016) 377 final].

European Parliament. (2014). "Humanitarian visas: option or obligation? Policy Department Citizens' Rights and Constitutional Affairs”, Study for the LIBE Committee. Brussels.

European Parliament. (2013a). Directive 2013/32/EU of the European Parliament and of the Council, of 26 June 2013, on common procedures for granting and withdrawing international protection (OJEU June 29, 2013).

European Parliament. (2013b). Directive 2013/33/EU of the European Parliament and of the Council, of 26 June 2013, laying down standards for the reception of applicants for international protection (OJEU June 29, 2013).

European Parliament. (2011). Directive 2011/95/EU of the European Parliament and of the Council, of 13 December 2011, on standards for the qualification of third-country nationals or stateless persons as beneficiaries of international protection, for a uniform status for refugees or for persons eligible for subsidiary protection, and for the content of the protection granted (OJEU December 20, 2011).

European Parliament. (2009). Regulation (EC) No. 810/2009 of the European Parliament and of the Council, of 13 July 2009, establishing a Community Code on Visas (Visa Code) (OJEU September 15, 2009).

European Parliament. (2008). Directive 2008/115/EC of the European Parliament and of the Council, of 16 December 2008, on common standards and procedures in Member States for returning illegally staying third-country nationals (OJEU December 24, 2008).

Eurostat. (2020). European Commission. Asylum and Managed Migration database. https:/ec.europa.eu/eurostat/web/asylum-and-managedmigration/data/main-tables

García-Juan, L. (2015). Medidas y condiciones de integración de inmigrantes: una propuesta europea difícil de articular en España. Migraciones, 38, 87-110. https://doi.org/10.14422/mig.i38.y2015.004

García Morales, M. J., Montilla Martos, J. A., y Arbós Marín, X. (2006). Las relaciones intergubernamentales en el Estadoautonómico. Foro Inmigración y Ciudadanía, Centro de Estudios Políticos y Constitucionales. Colección FORO $n^{\circ} 11$. 
Giménez Bachmann, M. (2015). La situación jurídica de los inmigrantes irregulares en España. Valencia: Tirant lo Blanch.

Groenendijk, K. (2006). Integration Policy and Community Law. In S. Carrera (Ed.), The Nexus between Immigration, Integration and Citizenship in the $E U$. CHALLENGE Collective Conference, 65, 7-9. Retrieved from https:// www.files.ethz.ch/isn/20641/Nexus_Immigration_Integration.pdf

Heidenreich, T., Lind, F., Eberl, J. M., \& Boomgaarden, H. G. (2019). Media Framing Dynamics of the 'European Refugee Crisis': A Comparative Topic Modelling Approach. Journal of Refugee Studies, 32, Special Issue(1), 172-182. https://doi.org/10.1093/jrs/fez025

Iglesias, J., Urrutia Asua, G., Buades Fuster, J., Estrada, C., y Vicente, T. (2018). ¿Acoger sin integrar? El Sistema de Acogida e integración y las condiciones de integración de la población refugiada en España. Sevilla: Asociación Claver. Retrieved from http://sjme.org/wp-content/ uploads/2018/02/Acoger-sin-integrar5.pdf

Izquierdo Escribano, A, y León-Alfonso, S. (2008). La inmigración hacia dentro. Argumentos sobre la necesidad de coordinación de las políticas de inmigración en un Estado multinivel. Política y sociedad, 45(1), 11 39. Retrieved from https://revistas.ucm.es/index.php/POSO/article/view/ POSO0808130011A

Klarenbeek, L. M. (2019). Reconceptualising 'integration as a two-way process', Migration Studies, 0(0), 1-20. https://doi.org/10.1093/migration/ mnz033

Lund, L. (2019). Effects of the Refugee Crisis on Perceptions of Asylum Seekers in Recipient Populations. Journal of Refugee Studies, 32, Special Issue(1), 219-237. https://doi.org/10.1093/jrs/fey070

Mayblin, L. (2019). Imagining asylum, governing asylum seekers: Complexity reduction and policy making in the UK Home Office. Migration Studies, 7(1), 1-20. https://doi.org/10.1093/migration/mnx060

Moya, D. (2010). Competència en matèria d'immigració. Revista Catalana de Dret Públic, Edición especial Sentència sobre l'Estatut, 355-361. Retrieved from http://revistes.eapc.gencat.cat/index.php/rcdp/article/view/160

Moya, D. (2008). Los informes municipales de arraigo social y disponibilidad de vivienda adecuada expedidos a los extranjeros extracomunitarios: el papel en Cataluña de la Oficina del Padrón Municipal. Cuadernos de Derecho Local, 17, 134-151. Retrieved from https://www.gobiernolocal. org/cuadernos-de-derecho-local-no-17/

Parshotam, A. (2017). The UN Global Compacts on Migration and Refugees: a new solution to migration management, or more of the same? South African Institute of International Affairs, occasional paper 273, November 2017. Retrieved from https://www.jstor.org/stable/ resrep25910?seq=1\#metadata_info_tab_contents

Piper, N., y Grugel, J. (2015). Global Migration Governance, Social Movements and the Difficulties of Promoting Migrant Rights. In M. 
Schierup, Likic-Brboric, and Neergaard (Eds.), Migration, Precarity, and Global Governance: Challenges and Opportunities for Labour (pp. 261-278). Oxford University Press. https://doi.org/10.1093/acprof:o so/9780198728863.003.0014

Rinken, S., Godenau, D., Martínez, A., \& Moreno, G. (2016). La integración de los inmigrantes en la sociedad española: debilidades y fortalezas en tiempos de crisis. Barcelona: Anuario CIDOB de la Inmigración. https:// doi.org/10.24241/AnuarioCIDOBInmi.2016.206

Rizcallah, C. (2019). Facing the Refugee Challenge in Europe: A Litmus Test for the European Union: A Critical Appraisal of the Common European Asylum System through the Lens of Solidarity and Human Rights. European Journal of Migration and Law, 21(2), 238-260. https://doi. org/10.1163/15718166-12340049

Rossi, E. (2017). Superseding Dublin: The European asylum system as a non-cooperative game. International Review of Law and Economics, 51, 50-59. https://doi.org/10.1016/j.irle.2017.06.003

Sebastiani, L. (2017). ¿Para quién y para qué son buenas las buenas prácticas? Unión Europea, integración de (in)migrantes y despolitización/ tecnificación de las políticas hegemónicas: un estudio de caso. EMPIRIA. Revista de Metodología de las Ciencias Sociales, 36, 39-62. https://doi. org/10.5944/empiria.36.2017.17858

Spanish State. (2000). Head of State. Act 4/2000, January 11, on the rights and freedoms of foreigners in Spain and their social integration (BOE No. 10, January 12, 2000).

Spanish State. (2003). Head of State. Act 14/2003, from November 20, amending the Act 4/2000, from January 11th, on rights and freedoms of foreigners in Spain and their social integration, modified by the Act 8/2000, from December 22 (BOE No. 279, form November 21, 2003).

Spanish State. (2011). Ministry of the Presidency. Royal Decree 557/2011, April 20, approving the Regulation of the Act 4/2000 on the rights and freedoms of foreigners in Spain and their social Integration, after its reform by Act 2/2009 (BOE No. 103, April 30, 2011).

Thielemann, E., \& Armstrong, C. (2013). Understanding European Asylum cooperation under the Schengen/Dublin system: a public goods framework. European Security, 22(2), 148-164. https://doi.org/10.1080/0 9662839.2012 .699892

Valenta, M., Nyamwathi, M., Jakobsen, J., \& Zuparić-Iljić, D. (2019). European Asylum Policies and the Stranded Asylum Seekers in Southeastern Europe. Journal of Refugee Studies, 32, Special Issue(1), 162-171. https://doi.org/10.1093/jrs/fey063

Van Niejenhuisa, C., Ottenb, S., \& Flachea, A. (2018). Sojourners' second language learning and integration. The moderating effect of multicultural personality traits. International Journal of Intercultural Relations, 63, 6879. https://doi.org/10.1016/j.ijintrel.2018.01.001 